\author{
PAULINA SZYJA \\ Uniwersytet Pedagogiczny w Krakowie, Polska \\ Pedagogical University of Cracow, Poland
}

\title{
Rola usług w wymianie międzynarodowej na przykładzie Singapuru
}

\section{The Role of Services in International Trade; the Example of Singapore}

\begin{abstract}
Streszczenie: Spośród trzech sektorów gospodarki: przemysłu, usług, rolnictwa, najważniejszą rolę odgrywają obecnie usługi. Ich rozwój powoduje szereg zmian nie tylko gospodarczych, ale i społecznych. W rezultacie wpływa na kształtowanie ram rozwojowych poszczególnych państw. Zakres usług, które są eksportowane, oraz ich rodzaje zależą od wielu czynników mających uzasadnienie popytowe, podażowe, a nawet strukturalne. Wpływają one na kształtowanie bilansu wymiany handlowej, zyski przedsiębiorstw, wymianę doświadczeń, rozwój współpracy, potencjał innowacyjny itd. Celem opracowania jest prezentacja roli usług w wymianie międzynarodowej ze wskazaniem ich zróżnicowania przedmiotowego oraz wpływu na zmiany w układach przestrzennych. Metoda badawcza bazuje na analizie danych statystycznych oraz studium przypadku Singapuru. Na podstawie przedstawionych rozważań można sądzić, że w przypadku niektórych państw rozwój eksportu usług może być podyktowany poszukiwaniem nowych przewag konkurencyjnych w sytuacji istnienia pewnych barier rozwojowych (np. terytorialnych lub środowiskowych) i prób ich przezwyciężenia.
\end{abstract}

\begin{abstract}
Of the three sectors of the economy: industry, services, agriculture, the most important role is played out by services. Their development causes a number of changes, not only economic, but also social. As a result, it influences on the shaping of development framework of each country. The range of services that are exported and their types depend on many factors with demand, supply, or even structural justifications. They influence on the development of the balance of trade, corporate profits, exchange of experiences, development of cooperation, innovation potential, and so on.The aim of the study is to present the role of services in international trade with emphasis on their diversity and the impact of the changes in spatial systems. The test method is based on the analysis of statistical data and case study of Singapore. The considerations allow to point out that in some countries, the development of export services may be dictated by the search for new competitive advantages where there are some barriers (for example territorial or environmental) to development and attempts to overcome them.
\end{abstract}

Słowa kluczowe: eksport; rozwój; środowisko; usługi

Keywords: development; environment; export; services

Otrzymano: 18 grudnia 2016

Received: 18 December 2016

Zaakceptowano: 12 lutego 2016

Accepted: 12 February 2016

Sugerowana cytacja / Suggested citation:

Szyja, P. (2017). Rola usług w wymianie międzynarodowej na przykładzie Singapuru. Prace Komisji Geografii Przemysłu Polskiego Towarzystwa Geograficznego, 31(1), 108-123. 


\section{WSTĘP}

Współcześnie w większości państw świata wiodącym pod względem udziału w kształtowaniu produktu krajowego brutto sektorem gospodarki są usługi. Ich pojęcie oraz zakres, a także kategoryzacja z uwagi na handlowy i niehandlowy wymiar powodują pewne trudności w analizie statystycznej. Bezsprzeczny pozostaje jednak ich rozwój, zarówno pod względem podmiotowym, jak i przedmiotowym.

Niniejsza publikacja podejmuje zagadnienia terminologiczne, a także praktyczne, związane z ujęciem statystycznym zjawiska.

Celem opracowania jest prezentacja roli usług w wymianie międzynarodowej ze wskazaniem ich zróżnicowania przedmiotowego oraz wpływu na zmiany w układach przestrzennych. Metoda badawcza bazuje na analizie danych statystycznych oraz studium przypadku Singapuru, w oparciu o wizytę studyjną.

\section{POJĘCIE I ZAKRES USŁUG}

Niektórzy eksperci podkreślają, że rozwój usług jest „efektem procesu ewolucji gospodarek od tych najprostszych, w których dominującą rolę odgrywa rolnictwo, przez bardziej złożone i oparte na przemyśle, aż do skoncentrowanych właśnie na usługach” (Mroczek, 2009: 196). Zdaniem Z. Zioło, w kontekście tworzenia ram rozwojowych „nadal podstawowe znaczenie ma działalność przemysłowa” (Zioło, 2013: 12). Jednocześnie jednak wyraźnie wrasta rola usług związanych z przemysłem.

Omawiane zagadnienie nastręcza pewnych trudności natury terminologicznej. Jest to podyktowane z jednej strony dynamiką zjawiska, a z drugiej powiązaniem z pozostałymi sektorami gospodarki. Zdaniem niektórych badaczy usługa to nic innego jak produkt (Rogoziński, 2012: 11-13). Inni twierdzą, że po dołączeniu usług do produktów trudno dokonać ich identyfikacji (Welsum, 2003: 6).

Jak podkreśla M. Stoma, trudności z ujęciem definicyjnym pojęcia „usługa” wynikają z: poszerzenia zakresu usług, rozbudowanego procesu przenikania usług i dóbr materialnych, różnorakiego zakresu działań w ramach usług, względów kulturowych, tradycji lub uwarunkowań geograficznych (Stoma, 2012: 125-126). W jednym z raportów Banku Światowego stwierdza się, że usługi są „niematerialne, niewidoczne”, często wymagają jednoczesnych procesów produkcji i konsumpcji (World Bank, 2002: 70). Z kolei M. Noland, D. Park i G.B. Estrada podkreślają dokonujące się zmiany w sektorze usług w Azji, biorąc pod uwagę zakres czasowy ich rozwoju oraz poziom dochodu. Wyróżniają tym samym „tradycyjne” usługi (takie jak usługi osobiste), które rozwijały się jako pierwsze, a które przynoszą niższe dochody, oraz usługi oparte na informacjach (np. biznesowe, komunikacyjne, komputerowe i techniczne), generujące większe zyski (Noland, Park, Estrada, 2013: 3).

Podejmując kwestię ujęcia definicyjnego usług, warto nawiązać do krajowego porządku prawnego. Ustawa o swobodzie działalności gospodarczej nie wyjaśnia omawianego zagadnienia wprost, a jedynie wymienia usługi wśród innych form działalności gospodarczej: „Działalnością gospodarczą jest zarobkowa działalność wytwórcza, budowlana, handlowa, usługowa oraz poszukiwanie, rozpoznawanie i wydobywanie kopalin ze złóż, a także działalność zawodowa, wykonywana w sposób zorganizowany i ciągły" (Obwieszczenie...; art. 2). 
Należy zauważyć pewien brak precyzji przy określaniu rodzaju działań i właściwości usług w omawianych przykładach wyjaśnienia terminu „usługa”. Pomocne w tym zakresie okazują się systemy klasyfikacyjne, np. NACE (akronim stosowany dla określenia statystycznej klasyfikacji działalności gospodarczej w Unii Europejskiej). Bez względu na nazwę, czyli niezależnie od tego, czy użyjemy określenia „przemysł usług, sektor usług czy po prostu usługi" (OECD, 2016), termin ten odnosi się do działalności gospodarczej, która została objęta następującymi sekcjami według wspomnianej nomenklatury w wersji 2 z 2008 roku (EUROSTAT, 2008: 57):

- G: handel hurtowy i detaliczny, naprawa pojazdów samochodowych i motocykli,

- H: transport i magazynowanie,

- I: działalność związana z zakwaterowaniem i usługami gastronomicznymi,

- J: informacja i komunikacja,

- K: działalność finansowa i ubezpieczeniowa,

- L: działalność związana z obsługą rynku nieruchomości,

- M: działalność profesjonalna, naukowa i techniczna,

- N: działalność w zakresie usług administrowania i działalność wspierająca,

- 0: administracja publiczna i obrona narodowa, obowiązkowe zabezpieczenia społeczne,

- P: edukacja,

- Q: opieka zdrowotna i pomoc społeczna,

- R: działalność związana z kulturą, rozrywką i rekreacją,

- S: pozostała działalność usługowa,

- T: gospodarstwa domowe zatrudniające pracowników; gospodarstwa domowe produkujące wyroby i świadczące usługi na własne potrzeby,

- U: organizacje i zespoły eksterytorialne.

W amerykańskiej klasyfikacji Standard Industrial Classification wyróżniono z kolei sekcje: transport, komunikacja, usługi gazowe, elektryczne i sanitarne, handel hurtowy, handel detaliczny, usługi finansowe, ubezpieczeniowe i związane z nieruchomościami, usługi, które ogólnie są określane mianem sektora świadczenia usług. Natomiast NAICS (Północnoamerykańska Klasyfikacja Działalności Gospodarczej) obejmuje: handel, transport, narzędzia, usługi informacyjne, usługi finansowe, usługi profesjonalne i biznesowe, usługi edukacji i zdrowia, usługi wypoczynku, inne usługi (BLS Information, 2017).

Na wspomnianej klasyfikacji NACE jest oparta Polska Klasyfikacja Działalności Gospodarczej. W ramach tej ostatniej zauważalne jest zróżnicowanie usług oraz szerokie spektrum form i sposobów aktywności w tej materii. W każdej ze wskazanych 21 sekcji można wyróżnić usługi, choć podstawowy ich zakres obejmuje 15 powyżej wspomnianych obszarów. Istotne jest zatem, że w niektórych przypadkach mamy do czynienia z całymi sekcjami (np. sekcja I - działalność związana z zakwaterowaniem i usługami gastronomicznymi), ale są też działy usług w ramach danej sekcji, które nie są wprost zaliczane do sektora usług, przykładowo w sekcji B - górnictwo i wydobywanie wyróżniono dział 9: działalność usługowa wspomagająca górnictwo i wydobywanie, a w innych wskazano jedynie grupy (tab. 1). Ponadto należy zwrócić uwagę na sekcje 0 i Q, które są związane z realizacją podstawowych funkcji państwa wobec obywateli. Z kolei sekcja U, odnosząca się do organizacji i zespołów eksterytorialnych, dotyczy m.in. regionalnych oddziałów międzynarodowych organizacji, takich jak Bank Światowy. 
Tab. 1. Przykłady usług w poszczególnych sekcjach usługowych Polskiej Klasyfikacji Działalności 2007 oraz sekcji, które nie są wskazane wprost jako usługowe

\begin{tabular}{|c|c|c|}
\hline Nazwa sekcji & Grupa/klasa/podklasa & Nazwa grupowania \\
\hline $\begin{array}{l}\text { A - ROLNICTWO, LEŚNICTWO, ŁOWIECTWO } \\
\text { I RYBACTWO }\end{array}$ & 01.62 & $\begin{array}{l}\text { Działalność usługowa } \\
\text { wspomagająca chów } \\
\text { i hodowlę zwierząt } \\
\text { gospodarskich }\end{array}$ \\
\hline $\begin{array}{l}\text { B - GÓRNICTWO I WYDOBYWANIE (dział } 09 \\
\text { działalność usługowa wspomagająca górnictwo } \\
\text { i wydobywanie) }\end{array}$ & 09.10 & \begin{tabular}{|l} 
Działalność usługowa \\
wspomagająca \\
eksploatację złóż ropy \\
naftowej i gazu ziemnego \\
\end{tabular} \\
\hline C - PRZETWÓRSTWO PRZEMYSŁOWE & 33.12 & $\begin{array}{l}\text { Naprawa i konserwacja } \\
\text { maszyn }\end{array}$ \\
\hline $\begin{array}{l}\text { D - WYTWARZANIE I ZAOPATRYWANIE } \\
\text { W ENERGIĘ ELEKTRYCZNĄ, GAZ, PARĘ WODNĄ, } \\
\text { GORACCĄ WODE I POWIETRZE DO UKŁADÓW } \\
\text { KLIMATYZACYJNYCH }\end{array}$ & 35.12 & $\begin{array}{l}\text { Przesyłanie energii } \\
\text { elektrycznej }\end{array}$ \\
\hline $\begin{array}{l}\text { E - DOSTAWA WODY; GOSPODAROWANIE } \\
\text { ŚCIEKAMI I ODPADAMI ORAZ DZIAŁALNOŚĆ } \\
\text { ZWIAZZANA Z REKULTYWACJA (dział } 39 \\
\text { działalność związana z rekultywacją i pozostała } \\
\text { działalność usługowa związana z gospodarką } \\
\text { odpadami) }\end{array}$ & $36.00 . Z$ & $\begin{array}{l}\text { Oczyszczanie wody } \\
\text { w celu jej dostawy, } \\
\text { sklasyfikowane w } 36.00 . \mathrm{Z}\end{array}$ \\
\hline $\begin{array}{l}\text { F - BUDOWNICTWO (dział } 41 \text { roboty budowlane } \\
\text { związane ze wznoszeniem budynków; dział } 42 \\
\text { roboty związane z budową obiektów inżynierii } \\
\text { lądowej i wodnej; dział } 43 \text { roboty budowlane } \\
\text { specjalistyczne) }\end{array}$ & 43.1 & $\begin{array}{l}\text { Rozbiórka } \\
\text { i przygotowanie terenu } \\
\text { pod budowę }\end{array}$ \\
\hline $\begin{array}{l}\text { G - HANDEL HURTOWY I DETALICZNY; NAPRAWA } \\
\text { POJAZDÓW SAMOCHODOWYCH, WŁĄCZAJĄC } \\
\text { MOTOCYKLE }\end{array}$ & 45.2 & $\begin{array}{l}\text { Konserwacja } \\
\text { i naprawa pojazdów } \\
\text { samochodowych, } \\
\text { z wyłączeniem motocykli }\end{array}$ \\
\hline $\begin{array}{l}\text { H - TRANSPORT I GOSPODARKA MAGAZYNOWA } \\
\text { (dział } 49 \text { transport lądowy oraz transport } \\
\text { rurociągowy; dział } 50 \text { transport wodny; dział } \\
51 \text { transport lotniczy; dział } 52 \text { magazynowanie } \\
\text { i działalność usługowa wspomagająca transport; } \\
\text { dział } 53 \text { działalność pocztowa i kurierska) }\end{array}$ & $53.10 . \mathrm{Z}$ & $\begin{array}{l}\text { Działalność pocztowa } \\
\text { objęta obowiązkiem } \\
\text { świadczenia usług } \\
\text { powszechnych }\end{array}$ \\
\hline $\begin{array}{l}\text { I - DZIAŁALNOŚĆ ZWIAZZANA } \\
\text { Z ZAKWATEROWANIEM I USŁUGAMI } \\
\text { GASTRONOMICZNYMI }\end{array}$ & 56.3 & $\begin{array}{l}\text { Przygotowywanie } \\
\text { i podawanie napojów }\end{array}$ \\
\hline $\begin{array}{l}\text { J - INFORMACJA I KOMUNIKACJA (dział } 63 \\
\text { działalność usługowa w zakresie informacji) }\end{array}$ & $63.91 . Z$ & $\begin{array}{l}\text { Działalność agencji } \\
\text { informacyjnych }\end{array}$ \\
\hline $\begin{array}{l}\text { K - DZIAŁALNOŚĆ FINANSOWA } \\
\text { I UBEZPIECZENIOWA (dział } 64 \text { finansowa } \\
\text { działalność usługowa, z wyłączeniem ubezpieczeń } \\
\text { i funduszy emerytalnych; dział } 65 \text { ubezpieczenia, } \\
\text { reasekuracja oraz fundusze emerytalne, } \\
\text { z wyłączeniem obowiązkowego ubezpieczenia } \\
\text { społecznego; dział } 66 \text { działalność wspomagająca } \\
\text { usługi finansowe oraz ubezpieczenia i fundusze } \\
\text { emerytalne) }\end{array}$ & $66.21 . Z$ & $\begin{array}{l}\text { Działalność związana } \\
\text { z oceną ryzyka } \\
\text { i szacowaniem } \\
\text { poniesionych strat }\end{array}$ \\
\hline $\begin{array}{l}\text { L - DZIAŁALNOŚĆ ZWIĄZANA Z OBSŁUGĄ RYNKU } \\
\text { NIERUCHOMOŚCI (dział } 68 \text { działalność związana } \\
\text { z obsługą rynku nieruchomości) }\end{array}$ & 68.31 & $\begin{array}{l}\text { Pośrednictwo w obrocie } \\
\text { nieruchomościami }\end{array}$ \\
\hline
\end{tabular}




\begin{tabular}{|c|c|c|}
\hline $\begin{array}{l}\text { M - DZIAŁALNOŚĆ PROFESJONALNA, NAUKOWA } \\
\text { I TECHNICZNA (dział } 69 \text { działalność prawnicza, } \\
\text { rachunkowo-księgowa i doradztwo podatkowe; } \\
\text { dział } 70 \text { działalność firm centralnych (head } \\
\text { office); doradztwo związane z zarządzaniem; } \\
\text { dział } 71 \text { działalność wakresie architektury } \\
\text { i inżynierii; badania i analizy techniczne; dział } \\
72 \text { badania naukowe i prace rozwojowe; dział } 73 \\
\text { reklama, badanie rynku i opinii publicznej; dział } \\
74 \text { pozostała działalność profesjonalna, naukowa } \\
\text { i techniczna; dział } 75 \text { działalność weterynaryjna) }\end{array}$ & $69.20 . Z$ & $\begin{array}{l}\text { Działalność rachunkowo- } \\
\text { księgowa; doradztwo } \\
\text { podatkowe }\end{array}$ \\
\hline $\begin{array}{l}\text { N - DZIAŁALNOŚĆ W ZAKRESIE USŁUG } \\
\text { ADMINISTROWANIA I DZIAŁALNOŚĆ } \\
\text { WSPIERAJĄCA (dział } 77 \text { wynajem i dzierżawa; } \\
\text { dział } 78 \text { działalność związana z zatrudnieniem; } \\
\text { dział } 79 \text { działalność organizatorów turystyki, } \\
\text { pośredników i agentów turystycznych oraz } \\
\text { pozostała działalność usługowa w zakresie } \\
\text { rezerwacji i działalności z nią związane; dział } 80 \\
\text { działalność detektywistyczna i ochroniarska; dział } \\
\text { 81 działalność usługowa związana z utrzymaniem } \\
\text { porządku w budynkach i zagospodarowaniem } \\
\text { terenów zieleni; dział } 82 \text { działalność związana } \\
\text { z administracyjną obsługą biura i pozostała } \\
\text { działalność wspomagająca prowadzenie } \\
\text { działalności gospodarczej) }\end{array}$ & $82.19 . \mathrm{Z}$ & $\begin{array}{l}\text { Wykonywanie fotokopii, } \\
\text { przygotowywanie } \\
\text { dokumentów i pozostała } \\
\text { specjalistyczna } \\
\text { działalność wspomagająca } \\
\text { prowadzenie biura }\end{array}$ \\
\hline $\begin{array}{l}\text { O - ADMINISTRACJA PUBLICZNA I OBRONA } \\
\text { NARODOWA; OBOWIĄZKOWE ZABEZPIECZENIA } \\
\text { SPOŁECZNE }\end{array}$ & 84.2 & $\begin{array}{l}\text { Usługi na rzecz całego } \\
\text { społeczeństwa }\end{array}$ \\
\hline P - EDUKACJA (dział 85 edukacja) & 85.59.A & Nauka języków obcych \\
\hline Q - OPIEKA ZDROWOTNA I POMOC SPOŁECZNA & 88.91.Z & $\begin{array}{l}\text { Opieka dzienna nad } \\
\text { dziećmi }\end{array}$ \\
\hline $\begin{array}{l}\text { R - DZIAŁALNOŚĆ ZWIAZZANA Z KULTURĄ, } \\
\text { ROZRYWKĄ I REKREACJĄ }\end{array}$ & $90.02 . Z$ & $\begin{array}{l}\text { Działalność } \\
\text { wspomagająca } \\
\text { wystawianie } \\
\text { przedstawień } \\
\text { artystycznych } \\
\end{array}$ \\
\hline $\begin{array}{l}\text { S - POZOSTAŁA DZIAŁALNOŚĆ USŁUGOWA (dział } \\
94 \text { działalność organizacji członkowskich; dział } 95 \\
\text { naprawa i konserwacja komputerów i artykułów } \\
\text { użytków osobistego i domowego; dział } 96 \\
\text { pozostała indywidualna działalność usługowa) }\end{array}$ & 96.02 & $\begin{array}{l}\text { Fryzjerstwo i pozostałe } \\
\text { zabiegi kosmetyczne }\end{array}$ \\
\hline $\begin{array}{l}\text { T - GOSPODARSTWA DOMOWE ZATRUDNIAJĄCE } \\
\text { PRACOWNIKÓW; GOSPODARSTWA DOMOWE } \\
\text { PRODUKUJĄCE WYROBY I ŚWIADCZĄCE USŁUGI } \\
\text { NA WŁASNE POTRZEBY (dział } 98 \text { gospodarstwa } \\
\text { domowe produkujące wyroby i świadczące usługi } \\
\text { na własne potrzeby) }\end{array}$ & $98.10 . \mathrm{Z}$ & $\begin{array}{l}\text { Gospodarstwa domowe } \\
\text { produkujące wyroby na } \\
\text { własne potrzeby }\end{array}$ \\
\hline U - ORGANIZACJE I ZESPOŁY EKSTERYTORIALNE & & \\
\hline
\end{tabular}

Źródło: opracowanie własne na podstawie Rozporządzenia Rady Ministrów z dnia 24 grudnia 2007 r. w sprawie Polskiej Klasyfikacji Działalności (2016)

Mimo ograniczeń definicyjnych, które nie pozwalają w pełni jednoznacznie określić omawianego terminu „usługa”, w opracowaniach pojawiają się definicje „handlu usługami”. Według Układu Ogólnego w sprawie Handlu Usługami (ang. General Agreement on Trade In Services) usługi handlowe to świadczenie: 
- z terytorium jednego państwa na terytorium któregokolwiek innego państwa,

- na terytorium jednego państwa dla usługobiorcy któregokolwiek innego państwa,

- przez usługodawcę jednego państwa poprzez obecność handlową na terytorium jakiegokolwiek innego państwa,

- przez usługodawcę jednego państwa poprzez obecność osób fizycznych państwa na terytorium któregokolwiek innego państwa (General Agreement.., 1995: 285-286).

Kolejna kwestia dotyczy rodzajów usług i usług podlegających umiędzynarodowieniu.

Przykładowo R.M. Stern i B.M. Hoekman wyróżnili cztery rodzaje usług w oparciu o mobilność usługodawców i usługobiorców:

- zarówno usługodawcy, jak i konsumenci nie muszą się przemieszczać (np. usługi świadczone elektronicznie),

- usługodawcy przemieszczają się do konsumentów (np. niektóre rodzaje konsultingu),

- konsumenci przemieszczają się do usługodawców (np. turystyka),

- zarówno konsumenci, jak i usługodawcy przemieszczają się (np. usługi rozrywkowe w trakcie mistrzostw świata w piłce nożnej zorganizowane przez Japonię i Koreę Południową w 2002 roku) (Stern, Hoekman, 1987: 39-60).

Z kolei Światowa Organizacja Handlu (World Trade Organization) wyróżnia następujące rodzaje usług podlegających umiędzynarodowieniu (Rynarzewski, ZielińskaGłębocka, 2006: 33):

- usługi biznesowe (a wśród nich: komputerowe, profesjonalne, np. prawne, marketingowe, techniczne, w zakresie wynajmu i leasingu, w zakresie rekrutacji pracowników, operacyjne, np. środków transportu, pozostałe, np. fotograficzne),

- komunikacyjne (pocztowe, telekomunikacyjne, audiowizualne),

- budowlane,

- dystrybucyjne (handel hurtowy i detaliczny, pośrednictwo),

- edukacyjne,

- w zakresie ochrony środowiska,

- finansowe (bankowe, ubezpieczeniowe),

- socjalne,

- turystyczne,

- w zakresie rekreacji, kultury i sportu,

- transportowe (transport morski, śródlądowy, lotniczy, drogowy, przesyłowy).

Każda z wymienionych kategorii jest dodatkowo rozbudowana o szereg szczegółowych typów.

Pomimo różnorakich ujęć i klasyfikacji, bezdyskusyjny pozostaje fakt wzrastającej roli usług zarówno w poszczególnych krajach, jak i w aspekcie międzynarodowej wymiany handlowej.

\section{ZNACZENIE USŁUG W WYMIANIE ŚWIATOWEJ}

Należy podkreślić, że pojawiają się pewne rozbieżności w opiniach dotyczących faktycznego wpływu sektora usług na wzrost gospodarczy. Według niektórych sektor ten może wspierać wzrost gospodarczy, według innych jest niezależny i nie zagraża tradycyjnym sektorom (Alhowaish, 2014: 1). Z kolei zdaniem innych badaczy usługi 
związane z żywieniem, zdrowiem, rekreacją, opieką nad dziećmi, a także powiązane z nimi usługi domowe i usługi związane z nieruchomościami oraz ubezpieczeniowe „odgrywają ważną rolę we wspieraniu działalności gospodarczej w gospodarce, właśnie ze względu na ich znaczenie dla gospodarstw domowych. Branże te dostarczają krytycznych usług lokalnych, które stanowią część infrastruktury społecznej dla rozwoju gospodarczego, poza jakimkolwiek wpływem na promocję eksportu" (Kay, Pratt, Warner, 2007: 437).

Dane statystyczne wskazują jednak jednoznacznie, że rośnie udział sektora usług w kształtowaniu produktu krajowego brutto większości państw świata. Udział usług w globalnym PKB kształtuje się obecnie na poziomie 68\% (World Bank, 2016). Rośnie także znaczenie sektora usług w wymianie handlowej. Średni udział eksportu i importu dóbr oraz usług komercyjnych w globalnym PKB wzrósł z poziomu 20\% w 1995 roku do 30\% w 2014 roku (WTO, 2015: 19). Warto również prześledzić zagadnienie roli sektora usług na tle przemysłu i rolnictwa w zakresie procentowego udziału w kształtowaniu światowego PKB (ryc. 1). 0 ile w przypadku usług widoczny jest wzrost z poziomu 58,30\% w 1995 roku, przez 65,58\% w 2004 roku i 67,32\% w 2010, aż do 68,47\% w 2014 roku, o tyle w pozostałych sektorach mamy do czynienia z tendencją malejącą. Odpowiednio dla przemysłu dane wyniosły: 33,85\% w 1995 roku, 29,78\% w 2004 roku, 28,73\% w 2010 roku, 27,62\% roku w 2014 roku. Natomiast dla rolnictwa dane w poszczególnych latach przedstawiają się następująco: 8,12\% (1995 rok), 4,80\% (2004 rok), 3,92\% (2010 rok), 3,88\% (2014 rok) (World Bank, 2016).

Rosnąca rola sektora usług wynika z takich czynników stymulujących ten stan rzeczy, jak: liberalizacja sektora, zmniejszenie liczby barier handlowych, rosnąca współzależność pomiędzy produkcją przemysłową i usługową (Rynarzewski, Zielińska-Głębocka, 2006: 31).

Wartość eksportu usług w ujęciu łącznym, czyli obejmująca wszystkie państwa członkowskie WTO, wyniosła w 2015 roku 4940 mld dol., a importu - 4780 mld dol.

Ryc. 1. Rola poszczególnych sektorów gospodarki w kształtowaniu globalnego PKB z uwzględnieniem wartości dodanej, wg Banku Światowego

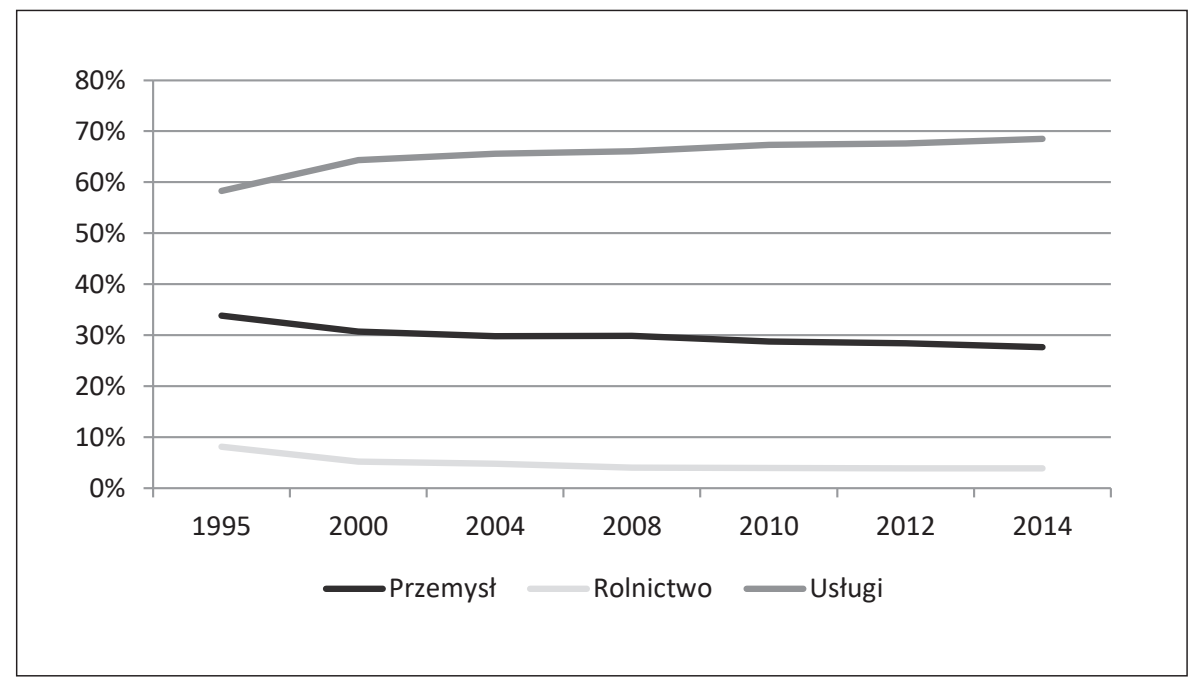

Źródło: dane Banku Światowego (2016) 
(WTO, 2015: 46). Liderów wymiany handlowej w omawianym zakresie i czasie prezentuje tab. 2.

Tab. 2. Liderzy eksportu i importu usług komercyjnych 2014

\begin{tabular}{|l|l|c|l|l|l|c|c|}
\hline \multicolumn{4}{|c|}{ Eksport } & \multicolumn{4}{c|}{ Import } \\
\hline Pozycja & \multicolumn{1}{|c|}{ Państwo } & $\begin{array}{c}\text { Wartość } \\
\text { (mln dol.) }\end{array}$ & Udział (\%) & Pozycja & Państwo & $\begin{array}{c}\text { Wartość } \\
\text { (mln dol) }\end{array}$ & Udział (\%) \\
\hline 1. & USA & 688 & 13,9 & 1. & USA & 452 & 9,4 \\
\hline 2. & Wielka Brytania & 337 & 6,8 & 2. & Chiny & 382 & 8,0 \\
\hline 3. & Francja & 267 & 5,4 & 3. & Niemcy & 326 & 6,8 \\
\hline
\end{tabular}

Źródło: WTO (2016)

Warto również zwrócić uwagę na typ dominujących obecnie usług podlegających umiędzynarodowieniu, ze wskazaniem przyczyn ich pozycji, a także na rosnące zainteresowanie tymi rodzajami usług, które do tej pory z różnych powodów cieszyły się mniejszą popularnością. Przykładami na pierwszy z omawianych przypadków, czyli usług w obszarze eksportu, wg typologii WTO, są (ryc. 2):

- inne usługi biznesowe (zgodnie z typologią WTO przydzielone do grupy „usługi biznesowe"),

- usługi podróżnicze (grupa „turystyczne i powiązane z podróżowaniem”),

- usługi finansowe, ubezpieczeniowe i emerytalne (grupa "finansowe"),

- usługi telekomunikacyjne, audiowizualne i powiązane, pocztowe i kurierskie (grupa „usługi komunikacyjne”).

Z kolei wiodącą rolę w imporcie usług odgrywają usługi (ryc. 3):

- transportowe,

- ubezpieczeniowe i emerytalne,

- podróżnicze.

Usługi biznesowe i finansowe są ze sobą ściśle skorelowane z uwagi na podstawowy wymiar organizacji funkcji przedsiębiorstw, który z jednej strony może wymagać m.in. zarządzania zasobami ludzkimi, doradztwa podatkowego, usług tłumaczeniowych, a z drugiej daje możliwości pozyskania kapitału za pośrednictwem banków. Z kolei usługi finansowe są intensyfikowane za sprawą rozszerzania działalności sektora finansowego poszczególnych państw na inne rynki, a także aspiracji stolic i metropolii wielu krajów do tworzenia centrum na wzór londyńskiego City. Przykładem pierwszego aspektu są banki chińskie. Według magazynu „Forbes” spośród 25 największych banków na świecie aż dziewięć pochodzi z Chińskiej Republiki Ludowej (Gara, 2016). Jeden z nich, Bank of China, działa obecnie w 29 państwach. Warto również wskazać, z uwagi na zakres terytorialny działania, na bank HSBC, założony w 1865 roku z myślą o wsparciu handlu pomiędzy Europą, Indiami i Chinami. Dziś bank ten funkcjonuje za pośrednictwem swoich placówek w 71 krajach i terytoriach (HSBC, 2016). Exemplum drugiego zjawiska jest rosnące znaczenie państw i miast, których władze, wykorzystując sprzyjające położenie geograficzne, a także poszukując nowych sposobów pozyskania inwestorów (np. rozbudowa infrastruktury), tworzą warunki zachęcające instytucje finansowe do otwierania swoich placówek na ich terenie, czyli Singapur, Hongkong (Williams, 2009: 517-577), Szanghaj (Zhao, 2013: 19-44). 
Ryc. 2. Udział poszczególnych rodzajów usług w eksporcie w skali globalnej

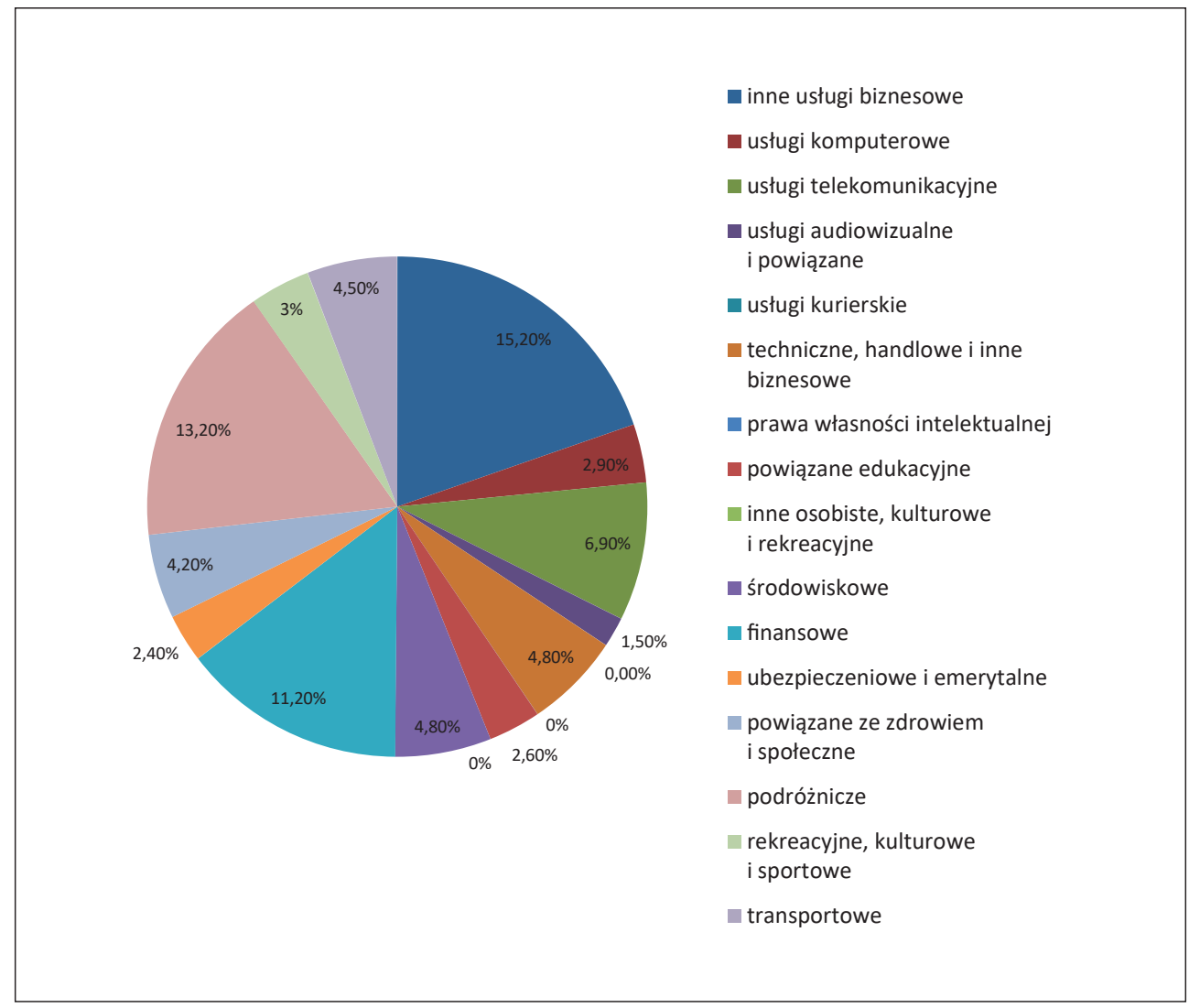

Źródło: opracowanie własne na podstawie: I-TIP Services (2016)

Z kolei rola usług komunikacyjnych wynika z postępu technologicznego oraz z globalizacji. Prowadzenie działalności gospodarczej wymaga nieustannego kontaktu z kontrahentami i klientami, a wręcz bycia dostępnym dla nich przez całą dobę.

Natomiast usługi podróżnicze są efektem większej dostępności tanich połączeń lotniczych, znoszenia ograniczeń paszportowych i celnych, a także upowszechnienia się języka angielskiego jako podstawowego w komunikacji interpersonalnej. Nie mniej istotne jest dostrzeżenie przez wiele państw korzyści finansowych związanych z napływem turystów.

Pozostałe typy usług, wg WTO, odgrywają mniejszą rolę. Są to usługi:

- techniczne, handlowe i inne biznesowe, prawa własności intelektualnej (grupa „usługi dystrybucji”),

- powiązane edukacyjne, inne osobiste, kulturowe i rekreacyjne (grupa „usługi edukacyjne),

- techniczne, handlowe i inne biznesowe (grupa „środowiskowe”),

- powiązane ze zdrowiem, inne osobiste, kulturowe i rekreacyjne (grupa „powiązane ze zdrowiem i społeczne"),

- inne osobiste, audiowizualne i powiązane, informacyjne, inne osobiste, kulturowe i rekreacyjne (grupa „rekreacyjne, kulturowe i sportowe”). 
Ryc. 3. Udział poszczególnych rodzajów usług w imporcie w skali globalnej

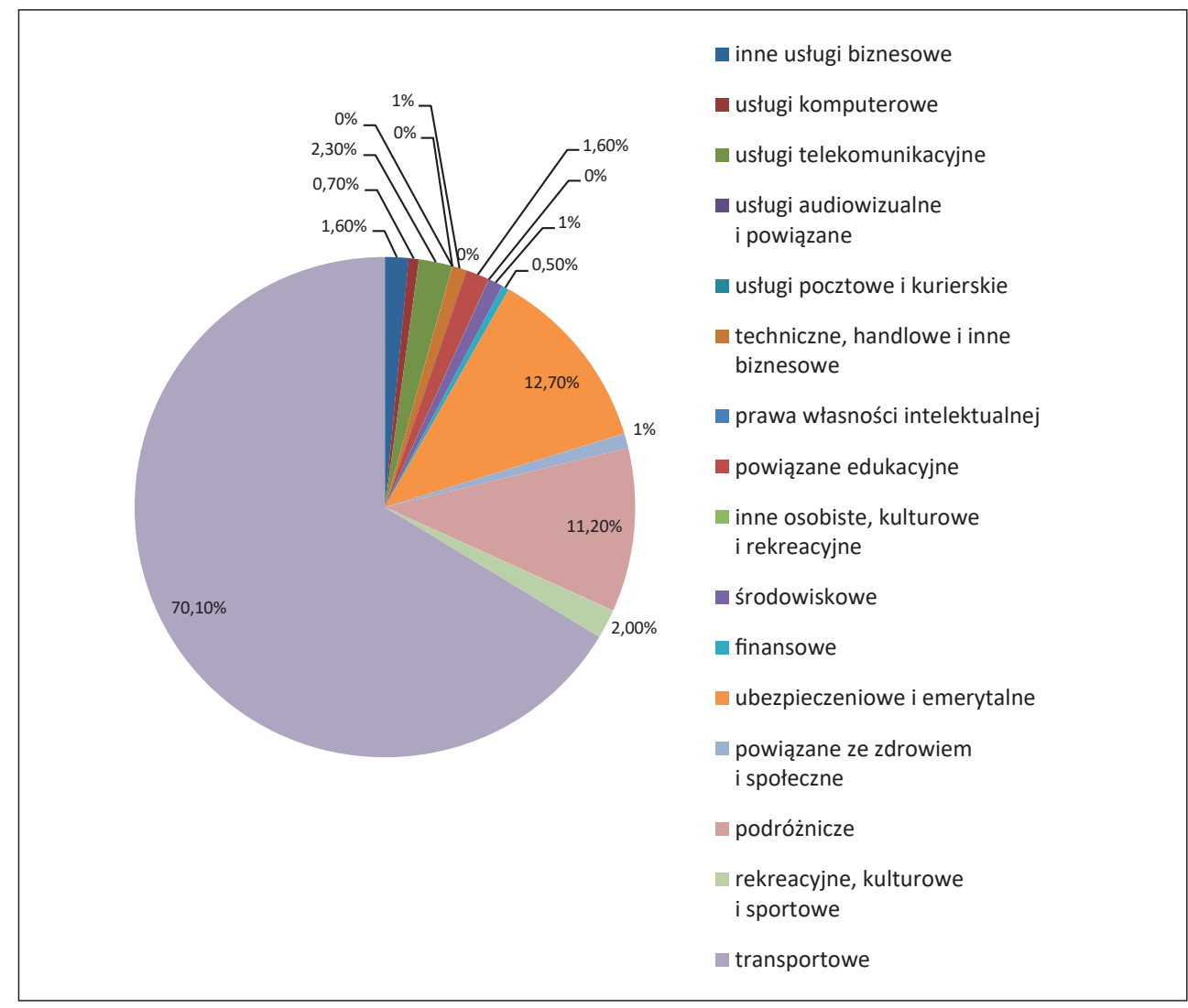

Źródło: opracowanie własne na podstawie: I-TIP Services (2016)

Warto zwrócić uwagę na te z nich, które są powiązane z ochroną środowiska. Ogólnie obejmują one usługi kanalizacyjne, sanitarne, usuwania odpadów, ograniczania emisji z pojazdów, redukcji hałasu, ochrony przyrody i krajobrazu oraz inne.

\section{EKSPORT I IMPORT USŁUG - PRZYPADEK SINGAPURU}

Singapur, niewielkie, bo liczące niespełna $720 \mathrm{~km}^{2}$, państwo w Azji Południowo-Wschodniej, jest obecnie liczącym się ośrodkiem wymiany handlowej. Według WTO, w 2015 roku był dziewiątą potęgą w zakresie handlu usługami (wartość 140 mld dol.) i dziesiątą w imporcie (141 mld dol.) (WTO, 2015: 6). Główni partnerzy handlowi Singapuru to kraje Unii Europejskiej, Stany Zjednoczone, państwa Association of South-East Asian Nations (ASEAN, Stowarzyszenie Narodów Azji Południowo-Wschodniej), Australia, Japonia i Chiny.

W eksporcie Singapuru dominują przede wszystkim takie usługi, jak: transportowe, finansowe, związane z podróżowaniem i zarządzaniem w biznesie (ryc. 4). Rozwój tych pierwszych jest związany z położeniem geograficznym Singapuru. Państwo jest wyspą otoczoną cieśninami Malakka (łącząca Morze Andamańskie z Morzem Południowochińskim) i Singapurską oraz Johor (pomiędzy Półwyspem Malajskim a Singapurem), 
Ryc. 4. Eksport usług Singapuru w 2014 roku

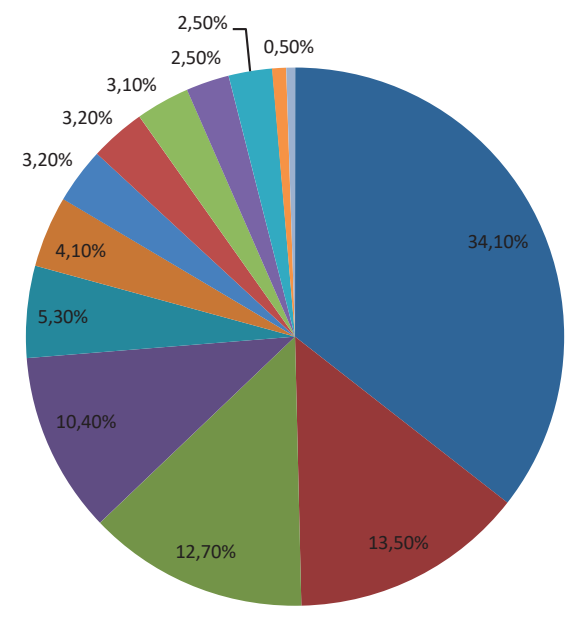

七 transport

minanse

podróże

- zarządzanie w biznesie

— konserwacja i naprawa

reklama i badania rynku

שsługi inżynieryjne i techniczne

- usługi telekomunikacyjne, komputerowe i informacyjne

usługi ubezpieczeniowe

uprawnienia do praw autorskich

usługi powiązane z handlem

usługi budowlane

badania i rozwój

Źródło: Department of Statistics Singapore (2016)

Ryc. 5. Import usług Singapuru w 2014 roku

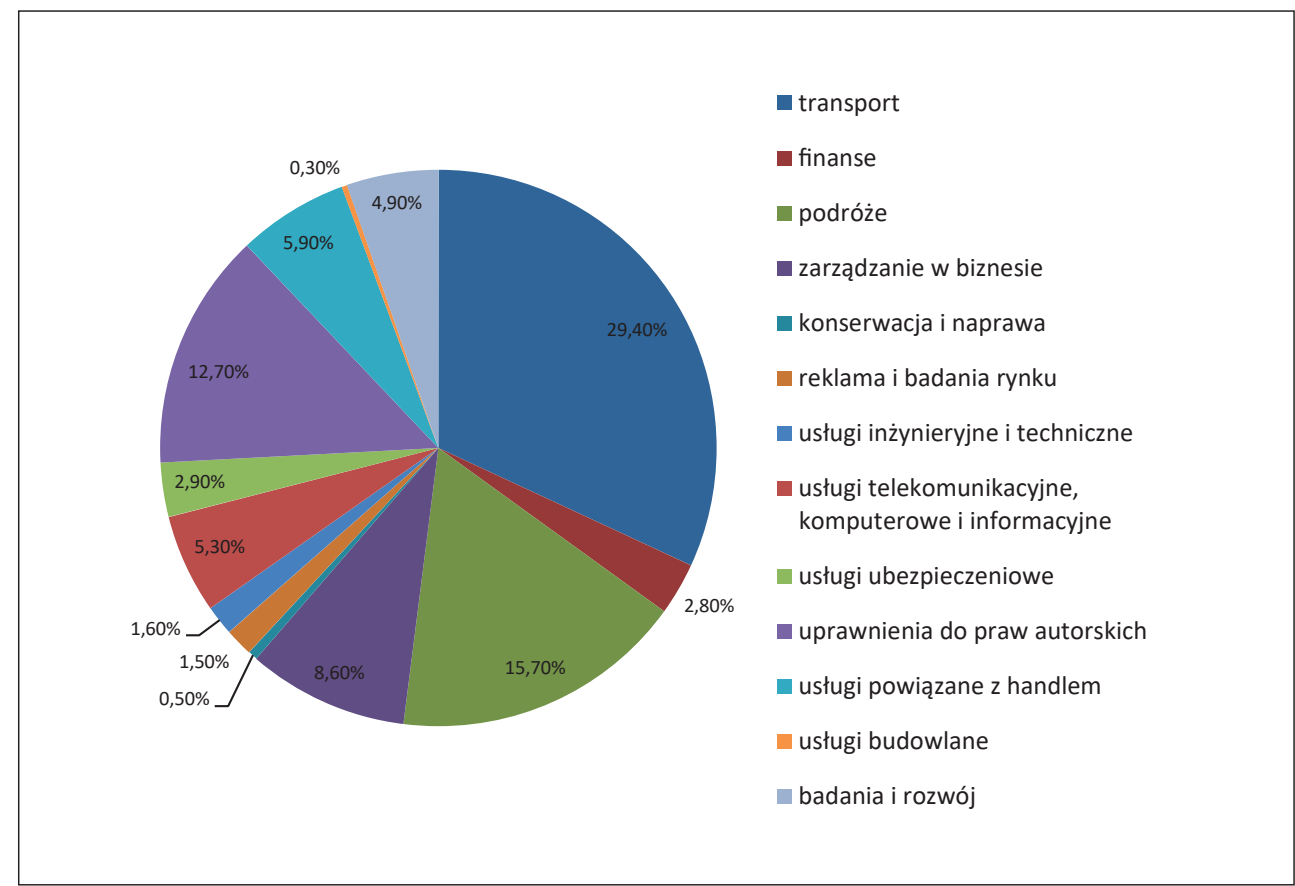

Źródło: Department of Statistics Singapore (2016) 
dzięki czemu stanowi idealne miejsce przeładunkowe. Dlatego też intensywnie rozwija się port, który zajmuje drugie miejsce na świecie pod względem liczby jednostek ładunkowych. To powoduje m.in. wysoki udział eksportu w wymianie handlowej, ale przede wszystkim reeksportu (Department of Statistics Singapore, 2016). Intensyfikacja usług finansowych w Singapurze jest związana z obecnością 1200 instytucji finansowych, a wśród nich pięciu banków lokalnych, 120 banków zagranicznych, holdingów finansowych, funduszy inwestycyjnych, firm ubezpieczeniowych i brokerskich (Monetary Authority of Singapore, 2016).

W imporcie Singapuru wiodącą rolę odgrywają usługi transportowe i związane z podróżowaniem, ale już na kolejnym miejscu należy wyróżnić pobieranie opłat za korzystanie z własności intelektualnej (ryc. 5). Te ostatnie obejmują opłaty i prowizje z tytułu używania patentów, wzorów przemysłowych, praw produkcyjnych, prawa franczyzowego itd. Przyczyną znaczenia tego rodzaju usług jest polityka władz Singapuru ukierunkowana na pozyskiwanie wiedzy, umiejętności oraz doświadczeń zagranicznych partnerów. Celem było (od momentu uzyskania niepodległości przez Singapur w 1965 roku) i jest kształtowanie rozwoju kapitału ludzkiego w zakresie podnoszenia jakości siły roboczej. Dlatego też władze jednocześnie stawiały na rozwój edukacji i pozyskiwanie zagranicznych inwestycji bezpośrednich, których rezultatem było uruchamianie różnego rodzaju zakładów produkcyjnych oraz sprowadzanie rozwiązań technologicznych i ekspertów. To pozwoliło na pozyskiwanie wiedzy i wdrażanie innowacji w gospodarce singapurskiej (Ghesquiere, 2007: 78), a jednocześnie stanowiło powód, dla którego Singapurczycy wyspecjalizowali się w kształtowaniu sprzyjających warunków inwestycyjnych, np. w postaci rozwiązań infrastrukturalnych.

Rozwój sektora usług w Singapurze to nie tylko efekt czynników wymienionych wcześniej czy procesów i ich następstw związanych z globalizacją, ale również konieczność podyktowana barierami rozwojowymi państwa w postaci: niewielkiego obszaru terytorialnego (co powoduje ograniczenia przestrzennej organizacji procesów produkcyjnych), braku surowców naturalnych (przede wszystkim energetycznych), braku wody i żywności (ryc. 6).

Eksport usług Singapuru jest oparty na umiejętnościach jego obywateli zdobytych przez 51 lat, a związanych m.in. z tworzeniem warunków sprzyjających inwestycji. Jednym z nich jest zapewnienie odpowiedniego stanu środowiska naturalnego. Dziś to

Ryc. 6. Powiązanie ograniczeń terytorialnych i rozwoju eksportu usług w Singapurze

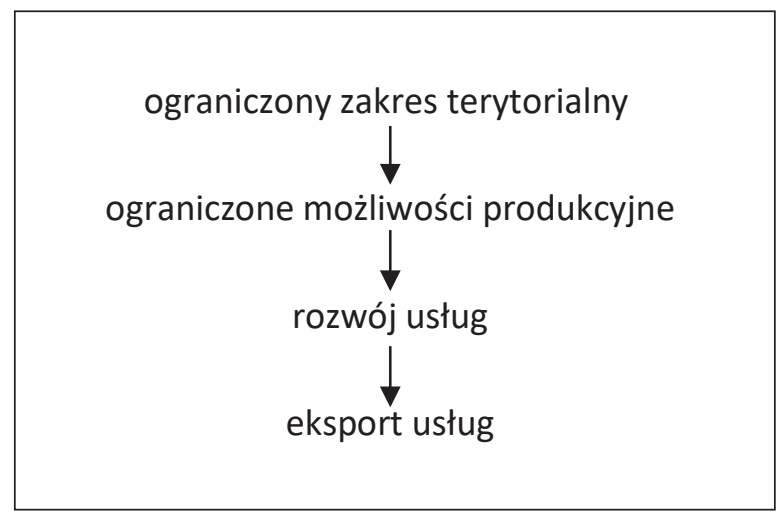

Źródło: opracowanie własne 
państwo-miasto jest określane mianem „azjatyckiego miasta ogrodu”. Tymczasem na początku istnienia państwo zmagało się z poważnymi problemami ekologicznymi, takimi jak np. zanieczyszczenie różnego rodzaju odpadami czy brakiem rozwiązań sanitarnych (Ghesquiere, 2007: 19). Dążenia ukierunkowane na pozyskanie zagranicznych inwestorów, a także na poprawę warunków życia mieszkańców, stały się przyczynkiem do wprowadzenia koniecznych zmian. Z czasem zakres przesłanek przemawiających za takimi działaniami rozszerzył się o: stopniowe ograniczanie barier rozwojowych, tworzenie przewag konkurencyjnych, pozyskiwanie klientów poza granicami kraju.

Główne obszary, w których intensyfikowano prace, objęły przede wszystkim: zarządzanie przestrzenią, rozwój infrastruktury, system zarządzania środowiskiem. W pierwszym aspekcie skupiono się na maksymalnym wykorzystaniu przestrzeni miejskiej zarówno pod względem organizacji węzłów komunikacyjnych, jak i dzielnic mieszkaniowych oraz przemysłu. Przy czym istotny nacisk położono na uwzględnienie zieleni w architekturze miejskiej, z uwagi na walory estetyczne i praktyczne, czyli zapewnienie naturalnej osłony przed promieniowaniem słonecznym. Ponadto rozwinięto infrastrukturę wodno-kanalizacyjną wraz z budową obiektów związanych z oczyszczaniem wody zarówno dla celów przemysłowych, jak i do picia (NEWater Plants). Zainwestowano także środki w zakład odsalania wody morskiej oraz w infrastrukturę gromadzenia wody deszczowej. Te projekty przyczyniają się do poprawy nie tylko warunków życia w Singapurze, ale i warunków inwestycyjnych (Yong Soon, Tung Jean, Tan, 2009: XXIV-XXV).

Nabyta wiedza i umiejętności pozwoliły na udzielanie wsparcia innym państwom poprzez podmioty publiczne, np. Singapurski Program Wsparcia Technicznego na rzecz Zrównoważonego Rozwoju (Singapore Technical Assistance Programme for Susiainable Development), Singapurski Instytut Środowiska (Singapore Environment Institute), a także instytucję wsparcia w zakresie wiedzy i technologii związanej z gospodarką wodną (WaterHub) (Yong Soon, Tung Jean, Tan, 2009: 280-283). W ostatnim czasie intensyfikuje się w Singapurze wysiłki na rzecz efektywności energetycznej i zastosowania technologii pozyskiwania energii ze źródeł odnawialnych. Działania w tym zakresie rozwija rządowa agenda zajmująca się budownictwem, Building and Construction Authority, której pracownicy wspierają swoją wiedzą inwestycje realizowane w Chinach.

Funkcjonuje też wiele przedsiębiorstw świadczących usługi w zakresie ochrony powietrza, oczyszczania wody, doradztwa środowiskowego, produkcji technologii środowiskowych i urządzeń ochrony środowiska. Rola tych dwóch ostatnich rośnie, o czym świadczą dane dotyczące rynku technologii środowiskowych w Singapurze (tab. 3).

Tab. 3. Rynek technologii ochrony środowiska w Singapurze

\begin{tabular}{|l|c|c|c|c|}
\cline { 2 - 4 } \multicolumn{1}{c|}{} & $\begin{array}{c}2014 \\
\text { (w mln dol.) }\end{array}$ & $\begin{array}{c}2015 \\
\text { (w mln dol.) }\end{array}$ & $\begin{array}{c}2016 \text { (szacowane } \\
\text { dane w mln dol.) }\end{array}$ & $\begin{array}{c}2017 \text { (szacowane } \\
\text { dane w mln dol.) }\end{array}$ \\
\hline $\begin{array}{l}\text { Rozmiar rynku } \\
\text { [(produkcja lokalna } \\
\text { import) - eksport] }\end{array}$ & 18321 & 18733 & 20232 & 22143 \\
\hline Produkcja lokalna & 18977 & 19357 & 20906 & 22878 \\
\hline Eksport & 10798 & 9874 & 10635 & 11593 \\
\hline Import & 10142 & 9223 & 9961 & 10858 \\
\hline
\end{tabular}

Źródło: Environment control equipment (2016) 
Usługi powiązane z technologiami środowiskowymi oraz zarządzaniem środowiskiem nie są wyraźnie wskazane w singapurskich statystykach. Choć ich udział jest minimalny, to jednocześnie imponujące są przedsięwzięcia w tym zakresie podejmowane przez Singapur w Chinach. Za sprawą międzyrządowego porozumienia tych dwóch państw w 2007 roku zainicjowano projekt Tianjin Eco-city. To ekologiczne miasto powstaje w odległości 150 km na zachód od Pekinu i 40 km od centrum miasta Tianjin, na terenach, które nie nadają się do uprawy rolnej, oraz borykają się z deficytem wody. Celem jest stworzenie miasta zapewniającego harmonię społeczną, przyjaznego dla środowiska naturalnego i wydajnego w zakresie wykorzystania surowców naturalnych. Miasto zajmuje $30 \mathrm{~km}^{2}$ powierzchni i jest przewidziane dla 350 tys. mieszkańców.

Projekt Tianjin Eco-city jest ważny dla Singapuru z kilku powodów:

- przyczynia się do wzrostu znaczenia ekspertów z Singapuru,

- pozwala na rozszerzenie aktywności biznesowej poza granice kraju i tym samym na przezwyciężenie barier związanych z ograniczonym terytorium (Economic development, 2016),

- umożliwia wymianę doświadczeń i wiedzy.

\section{WNIOSKI}

Usługi handlowe stanowią obecnie 68\% globalnego PKB. W eksporcie dominują usługi biznesowe, związane z podróżowaniem oraz finansowe. Z kolei w imporcie w oparciu o dane statystyczne należy wskazać usługi: transportowe, ubezpieczeniowe i emerytalne, podróżnicze. Rozwój tych rodzajów form aktywności gospodarczej jest związany głównie ze wsparciem przedsiębiorstw, zarówno w zakresie organizacji ich funkcjonowania, jak i zabezpieczenia kapitałowego. Warto podkreślić, że czynnikiem stymulującym usługi transportowe jest postęp techniczny. Z kolei popularność usług związanych z podróżowaniem to efekt z jednej strony większej dostępności środków komunikacji pomiędzy krajami i kontynentami, a z drugiej - dostrzeżenia roli sektora turystycznego w gospodarkach wielu państw.

Część usług odgrywa ważną rolę w kształtowaniu międzynarodowej wymiany handlowej. Inne, takie jak usługi edukacyjne, powiązane ze zdrowiem i społeczne czy też środowiskowe, przyczyniają się do rozwoju społeczno-gospodarczego na poziomie krajowym.

Różne są przesłanki intensyfikacji rozwoju sektora usług. Przykład stanowi Singapur, który podobnie jak wiele krajów regionu Azji Południowo-Wschodniej wspiera usługi, jednak motywy tej aktywności są nieco odmienne. Ograniczenia terytorialne w zakresie możliwości rozszerzenia procesów produkcyjnych powodują większą ekspansję wewnętrzną i zewnętrzną sektora usług. Dodatkowo wiedza i doświadczenie, zdobyte dzięki zagranicznym inwestycjom bezpośrednim, a także tworzenie odpowiednich warunków inwestycyjnych, pozwalają na kształtowanie przewag konkurencyjnych. Nie mniej istotne jest samo położenie kraju, które jest silnym czynnikiem upowszechniającym usługi transportowe.

Warto zwrócić uwagę na rolę usług środowiskowych w Singapurze. Ich udział, w ujęciu kompleksowym wymiany handlowej, jest niewielki. Należy jednak podkreślić, że ten szczególny rodzaj usług pozwala wyjaśnić, w jaki sposób działania związane z jednej strony z przezwyciężeniem barier rozwojowych czy oszczędzaniem i poprawą jakości życia, a z drugiej - z pewną praktycznością w zakresie tworzenia sprzyjających 
uwarunkowań inwestycyjnych i uzyskaną w ten sposób wiedzą, mogą stać się źródłem kooperacji z zagranicznymi partnerami.

Należy zauważyć, że omówiony przykład Singapuru jest dobrym wzorcem dla Polski. Kraj ten - pomimo sprzyjającego położenia geograficznego, dostępu do morza, zdolności do wytwarzania odpowiedniej ilości i jakości pożywienia, ogromnego potencjału ludzkiego, możliwości produkcyjnych, rozwoju usług - odnotowuje ujemny bilans handlowy. Pomimo braku barier rozwojowych na wzór Singapuru Polska nie potrafi wykorzystać możliwości, jakimi dysponuje, na rzecz kształtowania ram rozwojowych i zwiększenia swojej roli w wymianie międzynarodowej.

W zakresie roli usług w wymianie międzynarodowej warto byłoby zwrócić uwagę na takie kwestie, jak:

- powiązanie usług z innymi sektorami,

- udział usług środowiskowych w wymianie międzynarodowej,

- rola usług w kształtowaniu ram rozwojowych na płaszczyźnie międzynarodowej.

\section{Literatura \\ References}

Alhowaish, A.K. (2014). Does the Service Sector Cause Economic Growth? Empirical Evidence from Saudi Arabia. The Global Studies Journal, 7.

Bank Światowy (2016, 18 grudnia). Pozyskano z http://data.worldbank.org/indicator/NV.SRV. TETC.ZS; http://data.worldbank.org/indicator/NV.AGR.TOTL.ZS; http://data.worldbank. org/indicator/NV.IND.TOTL.ZS

BLS Information, Glossary (2017, 5 lutego). Pozyskano z https://www.bls.gov/bls/glossary.ht$\mathrm{m} \# \mathrm{~S}$

Department of Statistics Singapore (2016, 3 grudnia). Pozyskano z http://www.singstat.gov. sg/docs/default-source/default-documentlibrary/publications/publications_ and_papers/ international_trade/int-trade2014.pdf (Singapore's International Trade In Services 2014); http://www.singstat.gov.sg/statistics/latest-data

Economic development (2016, 15 grudnia). Pozyskano z http://www.tianjinecocity.gov.sg/col_ economic.htm

Environment control equipment (2017, 5 lutego). Pozyskano z http://2016.export.gov/singapore/doingbusinessinsingapore/leadingindustrysectors/index.asp\#P502_42131

EUROSTAT (2008). NACE Rev. 2. Statistical classification of economic activities in the European Community. Pozyskano z http://ec.europa.eu/eurostat/documents/3859598/5902521/ KS-RA-07-015-EN.PDF

Gara, A. (2016, 14 grudnia). The World's Largest Banks In 2016: China Keeps Top Three Spots But JPMorgan Rises. Pozyskano z http://www.forbes.com/sites/antoinegara/2016/05/25/ the-worlds-largest-banks-in-2016-china-keeps-top-three-spots-but-jpmorgan-rises/\#3c2ae1976230

General Agreement on Trade In Services (1995) (2016, 16 listopada). Pozyskano z https://www. wto.org/english/docs_e/legal_e/26-gats.pdf

Ghesquiere, H. (2007). Singapore's Success. Engineering Economic Growth. Singapore: Thomson.

HSBC. Nasza Firma (2016, 14 grudnia). Pozyskano z http://www.about.hsbc.pl/pl-pl/our-company

I-TIP Services (2016, 18 grudnia). Pozyskano z http://i-tip.wto.org/services/Search.aspx

Kay, D.L., Pratt, J.E., Warner, M.E. (2007). Role of Services in Regional Economy Growth. Growth and Change, 38(3), 419-442.

Monetary Authority of Singapore (2016, 15 grudnia). Types of Institutions. Pozyskano z http:// www.mas.gov.sg/singapore-financial-centre/types-of-institutions.aspx

Mroczek, A. (2009). Centra usług wyższego rzędu w aglomeracjach Polski na tle Unii Europejskiej i świata. W: S. Miklaszewski, E. Molendowski (red.). Gospodarka światowa w warunkach globalizacji i regionalizacji rynków. Warszawa: Difin, 196-216. 
Noland, M., Park, D., Estrada, G.B. (2013). Can a Growing Services Sector Renew Asia's Economic Growth? Asia Pacyfic Issues, 109.

Obwieszczenie Marszałka Sejmu Rzeczypospolitej Polskiej z dnia 8 kwietnia 2015 r. w sprawie ogłoszenia jednolitego tekstu ustawy o swobodzie działalności gospodarczej (Dz.U. z 2015 r. poz. 584).

OECD (2016, 5 lutego). Glossary of Statistical Terms. Pozyskano z https://stats.oecd.org/glossary/detail.asp?ID=2435

Rogoziński, K. (2012). Definicja usługi i to, co poniżej. Zeszyty Naukowe Uniwersytetu Szczecińskiego, 722(95), 11-25.

Rozporządzenie Rady Ministrów z dnia 24 grudnia 2007 r. w sprawie Polskiej Klasyfikacji Działalności (PKD) (Dz.U. z 2007 r. nr 251, poz. 1885).

Rynarzewski, T., Zielińska-Głębocka, A. (2006). Międzynarodowe stosunki gospodarcze. Teoria wymiany i polityki handlu międzynarodowego. Warszawa: Państwowe Wydawnictwo Naukowe.

Stern, R.M., Hoekman, B.M. (1987). Issues and data needs for GATT negotiations on services. The World Economy, 10, 39-60.

Stoma, M. (2012). Usługa jako kluczowy produkt współczesnego rynku - charakterystyka rynku usług w Polsce w ciągu ostatnich 10 lat. Zeszyty Naukowe Studia i Prace Kolegium Zarzadzania i Finansów, 120, 125-144.

Welsum, D., van (2003) (2016, 16 listopada). International Trade In Services: Issues and Concepts. Pozyskano z http://citeseerx.ist.psu.edu/viewdoc/download?doi=10.1.1.200.7797\&re$\mathrm{p}=\mathrm{rep} 1 \&$ type $=$ pdf

Williams, M. (2009). The Lion City and the Fragrant Harbor: The Political Economy of competition policy in Singapore and Hong Kong compared, Antitrust Bulletin, 54(3), 517-577.

World Bank (2002) (2016, 18 grudnia). Global economic Prospects and the Developing Countries. Pozyskano z http://documents.worldbank.org/curated/en/285571468337817024/31043 6360_20050012014722/additional/multi0page.pdf.

World Bank (2016, 16 listopada). World Bank national accounts data, and OECD National Accounts data files. Pozyskano z http://data.worldbank.org/indicator/NV.SRV.TETC.ZS

WTO (2015) (2016, 3 grudnia). International Trade Statistics 2015. Special focus: World trade and the WTO: 199-2014. Pozyskano z https://www.wto.org/english/res_e/statis_e/its2015_e/ its2015_e.pdf

Yong Soon, T., Tung Jean, L., Tan, K. (2009). Clean, Green and Blue. Singapore's Journey Towards Environmental and Water Sustainability. Singapore: Institute of Southeast Asian Studies.

Zhao, X. (2013). Shanghai's potential to become an international financial center. Journal of Academic Studies, 15(58), 19-44.

Zioło, Z. (2013). Rola przemysłu i usług w kształtowaniu gospodarki opartej na wiedzy. W: Z. Zioło, T. Rachwał. Funkcje przemysłu i usług w rozwoju gospodarki opartej na wiedzy. Prace Komisji Geografii Przemysłu Polskiego Towarzystwa Geograficznego, 21.

Paulina Szyja, dr, adiunkt w Katedrze Ekonomii i Polityki Gospodarczej, Uniwersytet Pedagogiczny w Krakowie. Zainteresowania naukowe: zrównoważony i trwały rozwój, międzynarodowa ochrona środowiska, bezpieczeństwo ekologiczne, zielona gospodarka.

Paulina Szyja, Ph.D., assistant professor at the Department of Economics and Economic Policy, Pedagogical University of Cracow. Scientific interests: sustainable development, international environmental protection, ecological safety, green economy.

\title{
Adres/address:
}

\author{
Uniwersytet Pedagogiczny w Krakowie \\ Katedra Ekonomii i Polityki Gospodarczej \\ ul. Podchorążych 2, 30-084 Kraków, Polska \\ e-mail: paulinaszyja@wp.pl
}

